\title{
PENERAPAN AKUNTANSI PERPAJAKAN ATAS KEPEMILIKAN AKTIVA KENDARAAN DENGAN METODE CAPITAL LEASE PADA PT IGLAS
}

\author{
Azaluddin \\ Program Studi Akuntansi, Fakultas Ekonomi \\ Universitas Muhammadiyah Buton No. 36 Baubau \\ E-mail:aza-hra75@yahoo.co.id
}

\begin{abstract}
Abstrak
Tujuan penelitian ini adalah untuk mengetahui penerapan akuntansi perpajakan atas kepemilikan aktiva kendaraan dengan metode capital lease pada PT IGLAS. Jenis penelitian ini adalah desktiptif kuantitatif. Lokasi penelitian ini berada di PT IGLAS. Hasil penelitian ini menunjukan bahwa (1) Perlakuan Akuntansi Sewa Guna Usaha atas kendaraan dinas selama tahun 2000-2004 di PT IGLAS hanya dari sisi akuntansi komersial saja, dari sisi fiskal belum diterapkan, padahal terdapat perbedaan-perbedaan perlakuan diantara keduanya. Misalkan masalah penyusutan, prinsip akuntansi komersial mengakui adanya penyusutan atas aktiva sewa guna usaha selama masa sewa guna usaha, sedangkan ketentuan fiskal tidak, ketentuan fiskal memperkenankan pengakuan penyusutan setelah lessee menggunakan hak opsinya untuk membeli aktiva tersebut; (2) Pembayaran angsuran sewa guna usaha yang dibayar setiap bulannya kepada lessor dicatat sebagai beban sewa oleh lessee dan menurut ketentuan perpajakan merupakan biaya yang deductable, yaitu dapat diakui sebagai biaya yang mengurangi Penghasilan bruto; dan (3) PPn Masukan atas pembelian aktiva kendaraan yang dilakukan oleh PT IGLAS, menurut ketentuan UU No. 18 tahun 2000 tentang Pajak Pertambahan Nilai, tidak dapat dikreditkan, sehingga pencatatannya dikapitalisaskan ke harga perolehan.
\end{abstract}

Kata kunci: akuntansi, aktiva, perusahaan.

\begin{abstract}
The purpose of this study was to determine the application of the tax accounting on asset ownership vehicle with a capital lease on a PT IGLAS. This research is a quantitative descriptive. The location of this research is in PT IGLAS. These results indicate that (1) Accounting Treatment for Leases on the official vehicles during 2000-2004 at PT IGLAS only from the commercial accounting, from the fiscal side has not been implemented, even though there are differences between the two treatments. Suppose shrinkage problems, commercial accounting principles recognize the depreciation of leased assets during the lease term, whereas the fiscal provisions do not, fiscal conditions permit the recognition of depreciation after the lessee to use its option right to purchase such assets; (2) Payment of lease installments paid each month to the lessor is recorded as an expense and lease by the lessee under the terms of a tax deductable expense, which can be recognized as expenses that reduce the gross income; and (3) Input VAT on the purchase of assets vehicles made by PT IGLAS, according to the provisions of Law No. 18 of 2000 on Value Added Tax, shall be credited, so that the recording dikapitalisaskan to the acquisition price.
\end{abstract}

Keywords: accounting, assets, company. 


\section{SANG PENCERAH}

Volume 3, Nomor 1, Februari 2017, Hlm. 23-32

Azaluddin: Penerapan Akuntansi Perpajakan Atas ...

\section{Pendahuluan}

Dana memegang peranan penting dalam menunjang kegiatan operasional perusahaan. Perusahaan dapat menggunakan dana tersebut sebagai alat investasi melalui penanaman barang modal. Dana yang diterima oleh perusahaan digunakan untuk membeli aktiva tetap, untuk memproduksi barang dan jasa, membeli bahan-bahan untuk kepentingan produksi dan penjualan, dan lain-lain. Dalam hal pengadaan barang modal, ada beberapa alternatif pembiayaan yang bisa dilakukan oleh perusahaan. Pembiayaan dari sumber internal dan pembiayaan dari sumber eksternal. Pembiayaan dari sumber internal dihasilkan sendiri di dalam perusahaan, diantaranya adalah laba ditahan, modal saham, dan lain-lain. Sedangkan pembiayaan dari sumber eksternal berasal dari luar perusahaan, diantaranya adalah pinjaman bank, sewa guna usaha (leasing), penjualan kredit dari pemasok, dan lain-lain.

Bagi perusahaan yang mempunyai modal besar, alternatif termudah adalah dengan menggunakan modal sendiri, sebaliknya bagi perusahaan yang tidak mempunyai cukup modal, alternatif yang dipilih adalah pembiayaan dari luar perusahaan. Salah satu jenis pembiayaan barang modal yang mulai banyak digunakan perusahaan di Indonesia selain pinjaman dari bank adalah pembiayaan Sewa Guna Usaha (Leasing). Sewa Guna Usaha (Leasing) adalah kegiatan pembiayaan dalam bentuk penyediaan barang modal baik secara sewa guna usaha dengan Hak Opsi (Capital Lease) maupun sewa guna usaha tanpa hak opsi (operating lease) untuk digunakan oleh lessee selama jangka waktu tertentu berdasarkan pembayaran secara berkala. Sewa guna usaha dengan hak opsi (financial lease) yaitu apabila dalam transaksi perusahaan lessor bertindak sebagai pihak yang membiayai barang modal dimana secara berkala lessor menerima pembayaran sewa guna usaha dari lessee dan di akhir masa sewa terdapat hak opsi bagi lessee. Hak opsi adalah hak lessee untuk membeli barang modal yang disewagunausahakan atau memperpanjang jangka waktu perjanjian sewa guna usaha. Sedangkan sewa guna usaha tanpa hak opsi (operating lease) yaitu apabila dalam transaksi perusahaan lessor membeli barang modal dan kemudian menyewa guna usahakannya kepada lessee, lessee tidak mempunyai hak opsi untuk membeli atau memperpanjang transaksi sewa guna usaha tersebut.

Pada setiap akhir periode, perusahaan selalu membuat laporan keuangan yang terdiri dari neraca dan laporan laba rugi. Dalam membuat laporan keuangan tersebut transaksi sewa guna usaha diperlakukan dan dicatat sebagai aktiva tetap dan kewajiban pada awal masa sewa guna usaha sebesar nilai tunai dari seluruh pembayaran sewa guna usaha ditambah nilai sisa (harga opsi) yang harus dibayar oleh penyewa guna usaha pada akhir masa sewa guna usaha. Perlakuan tersebut di atas adalah perlakuan yang biasa terjadi pada akuntansi komersial, perlakuan untuk perpajakan tentunya memiliki perbedaan dikarenakan adanya ketentuan-ketentuan perpajakan yang secara khusus mengaturnya. Adanya perbedaan tersebut memotivasi penulis untuk mencoba meneliti bagaimana perlakuan akuntansi perpajakan atas transaksi sewa guna usaha. Berdasarkan uraian di atas, fokus penelitian ini adalah bagaimanakah penerapan akuntansi perpajakan atas kepemilikan aktiva kendaraan dengan metode capital lease pada PT IGLAS?

Tujuan penelitian ini adalah untuk mengetahui penerapan akuntansi perpajakan atas kepemilikan aktiva kendaraan dengan metode capital lease pada PT IGLAS. 


\section{SANG PENCERAH}

Volume 3, Nomor 1, Februari 2017, Hlm. 23-32

Azaluddin: Penerapan Akuntansi Perpajakan Atas ...

\section{Metode Penelitian}

\section{Pendekatan Penelitian}

Noeng (2000:6) merupakan ilmu yang mempelajari tentang metode-metode penelitian, ilmu tentang alat-alat dalam penelitian. Selanjutnya Noeng (2000:3) mengatakan metodologi penelitian berbeda dengan metode penelitian. Metodologi penelitian membahas konsep teoritik berbagai metode, kelebihan dan kelemahannya, yang dalam karya ilmiah dilanjutkan dengan pemilihan metode yang digunakan, sedangkan metode penelitian mengemukakan secara teknis tentang metode-metode yang digunakan dalam penelitiannya.

\section{Jenis dan Sumber Data}

\section{Data Primer}

Data primer dalam penelitian ini diperoleh dari hasil wawancara dan pengamatan dengan pihak-pihak yang terkait. Dalam hal ini bagian umum, bagian akuntansi dan bagian pajak.

\section{Data Sekunder}

Merupakan data dari sumber tertulis, baik dari buku-buku literatur maupun dokumen-dokumen serta laporan-laporan yang diperoleh dari PT IGLAS.

\section{Prosedur Pengumpulan Data}

Prosedur pengumpulan data dalam penelitian ini dilakukan melalui tahap-tahap sebagai berikut.

\section{Survei Pendahuluan}

Peneliti membaca Laporan Auditor Independen PT IGLAS tahun 2004-2005 dan kemudian melakukan kunjungan awal ke perusahaan.

\section{Studi Kepustakaan}

Dilakukan dengan cara mengumpulkan dan mempelajari bukubuku dan literatur yang berhubungan dengan permasalahan penelitian.

\section{Survei Lapangan}

survei lanjutan yang dilakukan secara lebih mendalam dengan cara mengamati secara langsung pada perusahaan yang menjadi subjek penelitian. Survei lapangan terdiri dari:

a. Wawancara

Teknik pengumpulan data dengan melakukan tanya jawab dengan pihak-pihak terkait, dalam hal ini adalah bagian SDM dan umum, bagian akuntansi dan bagian pajak.

b. Observasi

Teknik pengumpulan data dengan cara mengadakan pengamatan tentang masalah penelitian, dalam hal ini mengenai perlakuan akuntansi pajak atas kepemilikan aktiva kendaraan dengan metode capital lease.

c. Dokumentasi

Teknik pengumpulan data dengan cara memeriksa atau melihat secara langsung dokumen, catatancatatan dan buku-buku yang digunakan perusahaan.

\section{Teknik Analisis Data}

Teknik analisis data yang digunakan dalam penelitian ini, yaitu (1) Menyusun data-data yang diperlukan yang berhubungan dengan perolehan aktiva kendaraan; (2) Menghitung perolehan aktiva kendaraan dengan metode capital lease; (3) Menerapkan perlakuan akuntansi perpajakan yang tepat atas transaksi; dan (4) Memberikan rekomendasi atau saran-saran kepada pihak manajemen.

\section{Pembahasan}

\section{Kebijakan Akuntansi Komersial PT IGLAS}

\section{Aktiva Tetap dan Penyusutannya}

Klasifikasi aktiva tetap dan nilai kapitalisasi (capital expenditure) ditetapkan dengan memo dinas direksi. Aktiva tetap 


\section{SANG PENCERAH}

Volume 3, Nomor 1, Februari 2017, Hlm. 23-32

Azaluddin: Penerapan Akuntansi Perpajakan Atas ...

dicatat sebesar nilai perolehannya. Penyusutan aktiva tetap dihitung dengan menggunakan metode garis lurus (straight-line method), berdasarkan taksiran masa manfaat ekonomis aktiva tersebut. Pada bulan Februari tahun 2006 direksi memutuskan untuk merevisi kebijakannya atas penyusutan aktiva tetap yang selama ini digunakan dengan pertimbangan (1) Berdasarkan pengalaman perusahaan, ternyata beberapa peralatan produksi mampu beroperasi lebih panjang dari umur teknis yang diperkirakan; dan (2) Pembebanan biaya penyusutan dengan umur aktiva yang lebih panjang akan mengurangi harga pokok produksi sehingga akan membantu kebijakan harga jual produk yang lebih kompetitif.

\section{Perbandingan}

kebijakan

penyusutan sebelum dan sesudah revisi dapat digambarkan sebagai berikut :

Tabel 1 Perbandingan Kebijakan Akuntansi Sebelum dan Sesudah Revisi

\begin{tabular}{|c|c|c|}
\hline \multirow[b]{2}{*}{ Jenis Aktiva } & \multicolumn{2}{|c|}{ Masa Penyusutan } \\
\hline & $\begin{array}{l}\text { Sebelum } \\
\text { revisi }\end{array}$ & $\begin{array}{c}\text { Setelah } \\
\text { revisi }\end{array}$ \\
\hline 1. Bangunan & 20 tahun & tetap \\
\hline \multicolumn{3}{|l|}{ 2. Mesin dan Perlengkapan } \\
\hline a. Dapur Peleburan & 7 tahun & 9 tahun \\
\hline b. Mesin-mesin produksi & 10 tahun & 15 tahun \\
\hline c. Mesin Pembangit tenaga & 10 tahun & 15 tahun \\
\hline d. Mesin Peralatan bengkel & 10 tahun & 15 tahun \\
\hline $\begin{array}{l}\text { e. Repair dapur dan mesin-mesin } \\
\text { (sesuai dengan sisa umur dapur } \\
\text { atau mesin yang direpair) }\end{array}$ & 2-3 tahun & tetap \\
\hline 3. Kendaraan & 5 tahun & tetap \\
\hline \multicolumn{3}{|l|}{ 4. Inventaris } \\
\hline a. Pallet dan trays & 3 tahun & tetap \\
\hline b. Peralatan kantor & 5 tahun & tetap \\
\hline c. Peralatan rumah dinas & 5 tahun & tetap \\
\hline Sumber: $\quad$ SK & PT & IGLAS \\
\hline
\end{tabular}

Tanah dinyatakan berdasarkan biaya perolehan dan tidak disusutkan. Biaya pengurusan hak atas tanah dikelompokkan ke dalam aktiva tetap tanah dan diamortisasi selama 20 tahun. Aktiva tetap yang sudah tidak digunakan lagi atau yang dijual dikeluarkan dari kelompok aktiva tetap berikut akumulasi penyusutannya. Keuntungan atau kerugian dari penjualan aktiva tetap tersebut dibukukan dalam (pendapatan/biaya lain-lain) pada tahun yang bersangkutan. Mould dinilai berdasarkan nilai perolehan dan dibebankan secara bertahap pada saat digunakan untuk produksi. Perhitungan penyusutannya didasarkan pada jumlah unit botol yang diproduksi (unit of production method). Sedangkan mould yang rusak sebelum taksiran kapasitas unit produksinya habis atau mould yang dapat dipakai melebihi taksiran kapasitas unit produksi tetap dibebankan dan dimasukkan ke R/L lainlain.

Beban pemeliharaan dan perbaikan dibebankan pada laporan laba rugi pada saat terjadinya. Pengeluaran yang memperpanjang masa manfaat atau memberi manfaat ekonomik di masa yang akan datang dalam bentuk peningkatan kapasitas, mutu produksi atau peningkatan standar kinerja dikapitalisasi.

\section{Aktiva Sewa Guna Usaha}

a. Capital lease

Aktiva sewa guna usaha dicatat sebagai aktiva tetap sebesar nilai tunai pembayaran sewa guna usaha selama masa sewa guna usaha yang ditetapkan pada saat permulaan sewa guna usaha. Selama masa sewa guna usaha biaya pemeliharaan menjadi beban penyewa (lessee). Penyusutan aktiva sewa guna usaha dihitung dengan metode garis lurus dengan masa manfaat ekonomis sama dengan aktiva tetap lainnya (lihat tabel 1).

Kewajiban sewa guna usaha disajikan terpisah dari kewajiban lainnya. 


\section{SANG PENCERAH}

Volume 3, Nomor 1, Februari 2017, Hlm. 23-32

Azaluddin: Penerapan Akuntansi Perpajakan Atas ...

\section{Transaksi Sewa Guna Usaha pada PT IGLAS}

Transaksi sewa guna usaha yang dilakukan PT IGLAS selama ini adalah transaksi pengadaaan kendaraan. Kendaraan tersebut digunakan untuk menunjang kegiatan operasional perusahaan. Adapun alasan-alasan perusahaan memilih pembelian kendaraan dengan cara leasing karena (1) Masa pemrosesan pembiayaan yang diajukan membutuhkan waktu yang relatif singkat dan prosedurnya mudah; (2) Leasing dapat memberi pembiayaan sampai $100 \%$ atas barang yang disewa; (3) Menghemat modal kerja; (4) Sewa guna usaha tidak menuntut jaminan tambahan yang berarti; (5) Melindungi dari resiko keusangan; dan (6) Dalam kondisi moneter yang tidak menentu, perusahaan terhindar dari pengaruh keadaan moneter misalnya inflasi.

Sewa guna usaha yang dilakukan PT IGLAS adalah sewa guna usaha dengan hak opsi (capital lease) dengan teknis pelaksanaan sewa guna usaha langsung (direct lease). Berikut ini penulis sajikan daftar kendaraan yang diperoleh PT IGLAS secara capital lease selama tahun 2001 hingga 2004.

Tabel 2 Daftar Aktiva Sewa Guna Usaha PT IGLAS Tahun 2001-2004

\begin{tabular}{|c|c|c|c|c|c|c|}
\hline \multirow{3}{*}{ REKENING } & \multirow{3}{*}{ KETERANGAN } & \multirow{3}{*}{$\begin{array}{l}\text { J } \\
\text { M } \\
\text { L }\end{array}$} & TAHUN & LAMA & NILAI & PENY. \\
\hline & & & \multirow[t]{2}{*}{ PEROLEHAN } & \multirow{2}{*}{$\begin{array}{l}\text { PENY. } \\
\text { (Th) }\end{array}$} & \multirow{2}{*}{$\begin{array}{c}\text { PEROL } \\
\text { EHAN } \\
\text { (Rp.) }\end{array}$} & \multirow{2}{*}{$\begin{array}{c}\text { Per Bulan } \\
\text { (Rp.) }\end{array}$} \\
\hline & & & & & & \\
\hline 121.12.1009 & $\begin{array}{l}\text { T.KIJANG LGX/P- } \\
\text { 5527-1101 } \\
\text { L 2559 NM }\end{array}$ & 1 & 30-11-2001 & 5 & $\begin{array}{c}188,987 \\
091.00\end{array}$ & $3,149,784.85$ \\
\hline 121.12 .1010 & $\begin{array}{l}\text { T.KIJANG } \\
\text { LGX/L-2784NM }\end{array}$ & 1 & $31-12-2001$ & 5 & $\begin{array}{l}\text { 188,987, } \\
091.00\end{array}$ & $3,149,784.85$ \\
\hline 121.12.1011 & $\begin{array}{l}\text { T.KIJANG } \\
\text { LGX/L-2731NM }\end{array}$ & 1 & $31-12-2001$ & 5 & $\begin{array}{l}\text { 188,987, } \\
091.00\end{array}$ & $3,149,784.85$ \\
\hline 121.12.1012 & $\begin{array}{l}\text { ISUZU } \\
\text { PANTHER L- } \\
\text { 2414PW }\end{array}$ & 1 & $12 / 31 / 2004$ & 5 & $\begin{array}{c}154,751, \\
798.00\end{array}$ & $2,579,196.63$ \\
\hline & Jumlah & & & & $\begin{array}{l}721,713, \\
071.00\end{array}$ & $\begin{array}{c}12,028,551.1 \\
8\end{array}$ \\
\hline
\end{tabular}

Pihak-pihak yang terlibat dalam transaksi Sewa Guna Usaha tersebut adalah:
1. Pihak Pertama (Lessee): PT IGLAS

2. Pihak Kedua (Lessor) : Oto Multi Artha

Rincian transaksinya adalah sebagai berikut (1) Tiga unit Toyota Kijang LGX. Transaksi dilakukan pada bulan Desember 2001 dengan jangka waktu perjanjian selama 4 tahun. Kendaraan tersebut digunakan untuk menunjang kegiatan operasional perusahaan.

a. Harga Barang @Rp188.987.091 X 3 unit : Rp566.961.273,00

b. Bunga 4 tahun @ 10\% : Rp163.668.462,00

c. Angsuran per bulan : Rp10.701.284,00

d. Nilai Sisa (Hak opsi) @Rp72.000.000 X 3 unit : Rp216.000.000,00

Satu unit Isuzu Panther LM 2.5 Plus C (SMART) Manual tahun 2004 warna perak metalik. Transaksi dilakukan pada bulan Desember 2004 dengan jangka waktu perjanjian selama 4 tahun. Kendaraan tersebut digunakan untuk fasilitas antar jemput karyawan.

a. Harga Barang : Rp154.751.798,00

b. Bunga 4 tahun @ 7,5\% : Rp34.683.281,00

c. Angsuran per bulan : Rp2.531.574,00

d. Nilai Sisa (Hak opsi) : Rp67.500.000,00

Tabel 3 Jadwal Pembayaran Sewa Guna Usaha 3 Unit Toyota Kijang LGX

\begin{tabular}{|c|c|c|c|c|}
\hline Tg1 & Angsuran & Bunga & Pokok & Sisa \\
\hline & & & & Rp566,961,272.09 \\
\hline January 02 & Rp10,701,284.55 & Rp4,705,778.56 & Rp5,995,505.99 & Rp560,965,766.10 \\
\hline February 02 & Rp10,701,284.55 & $\mathrm{Rp} 4,656,015.86$ & $\mathrm{Rp} 6,045,268.69$ & Rp554,920,497.41 \\
\hline March 02 & Rp10,701,284.55 & Rp4,605,840.13 & Rp6,095,444.42 & Rp548,825,052.99 \\
\hline April 02 & Rp10,701,284.55 & Rp4,555,247.94 & $\mathrm{Rp} 6,146,036.61$ & Rp542,679,016.38 \\
\hline May 02 & Rp10,701,284.55 & Rp4,504,235.84 & $\mathrm{Rp} 6,197,048.71$ & Rp536,481,967.66 \\
\hline June 02 & Rp10,701,284.55 & Rp4,452,800.33 & Rp6,248,484.22 & Rp530,233,483.44 \\
\hline July 02 & Rp10,701,284.55 & Rp4,400,937.91 & $\mathrm{Rp} 6,300,346.64$ & Rp523,933,136.81 \\
\hline August 02 & Rp10,701,284.55 & $\mathrm{Rp} 4,348,645.04$ & $\mathrm{Rp} 6,352,639.51$ & Rp517,580,497.29 \\
\hline September 02 & Rp10,701,284.55 & Rp4,295,918.13 & Rp6,405,366.42 & Rp511,175,130.87 \\
\hline October 02 & Rp10,701,284.55 & Rp4,242,753.59 & Rp6,458,530.96 & Rp504,716,599.90 \\
\hline November 02 & Rp10,701,284.55 & Rp4,189,147.78 & Rp6,512,136.77 & Rp498,204,463.13 \\
\hline December 02 & Rp10,701,284.55 & $\mathrm{Rp} 4,135,097.04$ & Rp6,566,187.51 & Rp491,638,275.63 \\
\hline January 03 & Rp10,701,284.55 & Rp4,080,597.69 & $\mathrm{Rp} 6,620,686.86$ & Rp485,017,588.77 \\
\hline February 03 & Rp10,701,284.55 & Rp4,025,645.99 & $\mathrm{Rp} 6,675,638.56$ & Rp478,341,950.20 \\
\hline March 03 & Rp10,701,284.55 & Rp3,970,238.19 & $\mathrm{Rp} 6,731,046.36$ & Rp471,610,903.84 \\
\hline April 03 & Rp10,701,284.55 & Rp3,914,370.50 & $\mathrm{Rp} 6,786,914.05$ & Rp464,823,989.79 \\
\hline May 03 & Rp10,701,284.55 & $\mathrm{Rp} 3,858,039.12$ & $\mathrm{Rp} 6,843,245.43$ & Rp457,980,744.36 \\
\hline
\end{tabular}




\section{SANG PENCERAH}

Volume 3, Nomor 1, Februari 2017, Hlm. 23-32

Azaluddin: Penerapan Akuntansi Perpajakan Atas ...

\begin{tabular}{|c|c|c|c|c|}
\hline June 03 & Rp10,701,284.55 & $\mathrm{Rp} 3,801,240.18$ & Rp6,900,044..37 & Rp451,080,699.98 \\
\hline July 03 & Rp10,701,284.55 & $\mathrm{Rp} 3,743,969.81$ & Rp6,957,314.74 & Rp444,123,385.24 \\
\hline August 03 & Rp10,701,284.55 & $\mathrm{Rp} 3,686,224.10$ & Rp7,015,060.45 & Rp437,108,324.79 \\
\hline September 03 & Rp10,701,284.55 & $\mathrm{Rp} 3,627,999.10$ & Rp7,073,285.45 & Rp430,035,039.34 \\
\hline October 03 & Rp10,701,284.55 & Rp3,569, 290.83 & Rp7,131,993.72 & Rp422,903,045.61 \\
\hline November 03 & Rp10,701,284.55 & Rp3,510,095.28 & Rp7,191,189.27 & Rp415,711,856.34 \\
\hline December 03 & Rp10,701,284.55 & Rp3,450,408.41 & $\mathrm{Rp} 7,250,876.14$ & Rp408,460,980.20 \\
\hline January 04 & Rp10,701,284.55 & $\mathrm{Rp} 3,390,226.14$ & $\mathrm{Rp} 7,311,058.41$ & Rp401,149,921.79 \\
\hline February 04 & Rp10,701,284.55 & $\mathrm{Rp} 3,329,544.35$ & Rp7,371,740.20 & Rp393,778,181.59 \\
\hline March 04 & Rp10,701,284.55 & $\mathrm{Rp} 3,268,358.91$ & $\mathrm{Rp7}, 432,925.64$ & Rp386,345,255.94 \\
\hline April 04 & Rp10,701,284.55 & $\mathrm{Rp} 3,206,665.62$ & $\mathrm{Rp7} 7494,618.93$ & Rp378,850,637.02 \\
\hline May 04 & Rp10,701,284.55 & Rp3,144,460.29 & $\mathrm{Rp} 7,556,824.26$ & Rp371,293,812.76 \\
\hline June 04 & Rp10,701,284.55 & Rp3,081,738.65 & Rp7,619,545.90 & Rp363,674,266.85 \\
\hline July 04 & Rp10,701,284.55 & Rp3,018,496.41 & Rp7,682,788.14 & Rp355,991,478.72 \\
\hline August 04 & Rp10,701,284.55 & Rp2,954,729.27 & $\mathrm{Rp} 7,746,555.28$ & Rp348,244,923.44 \\
\hline September 04 & Rp10,701,284.55 & Rp2,890,432.86 & Rp7,810,851.69 & Rp340,434,071.75 \\
\hline October 04 & Rp10,701,284.55 & Rp2,825,602.80 & $\mathrm{Rp7,875,681.75}$ & Rp332,558,390.00 \\
\hline November 04 & Rp10,701,284.55 & $\mathrm{Rp} 2,760,234.64$ & $\mathrm{Rp7,941,049.91}$ & Rp324,617,340.09 \\
\hline December 04 & Rp10,701,284.55 & Rp2,694,323.92 & Rp8,006,960.63 & Rp316,610,379.46 \\
\hline January 05 & Rp10,701,284.55 & Rp2,627,866.15 & Rp8,073,418.40 & Rp308,536,961.06 \\
\hline February 05 & Rp10,701,284.55 & Rp2,560,856.78 & Rp8,140,427.77 & Rp300,396,533.29 \\
\hline March 05 & Rp10,701,284.55 & Rp2,493,291.23 & Rp8,207,993.32 & Rp292,188,539.96 \\
\hline April 05 & Rp10,701,284.55 & Rp2,425,164.88 & Rp8,276,119.67 & Rp283,912,420.29 \\
\hline May 05 & Rp10,701,284.55 & Rp2,356,473.09 & Rp8,344,811.46 & Rp275,567,608.83 \\
\hline June 05 & Rp10,701,284.55 & Rp2,287,211.15 & Rp8,414,073.40 & Rp267,153,535.44 \\
\hline July 05 & Rp10,701,284.55 & Rp2,217,374.34 & Rp8,483,910.21 & Rp258,669,625.23 \\
\hline August 05 & Rp10,701,284.55 & Rp2,146,957.89 & Rp8,554,326.66 & Rp250,115,298.57 \\
\hline September 05 & Rp10,701,284.55 & Rp2,075,956.98 & $\mathrm{Rp} 8,625,327.57$ & Rp241,489,971.00 \\
\hline October 05 & Rp10,701,284.55 & Rp2,004,366.76 & Rp8,696,917.79 & Rp232,793,053.21 \\
\hline November 05 & Rp10,701,284.55 & Rp1,932,182.34 & Rp8,769,102.21 & Rp224,023,951.00 \\
\hline December 05 & Rp10,701,284.55 & Rp1,859,398.79 & Rp8,841,885.76 & Rp215,182,065.24 \\
\hline \multirow[t]{2}{*}{ January 06} & Rp216,000,000.00 & Rp1,786,011.14 & Rp215,182,065.24 & Rp0.00 \\
\hline & $\operatorname{Rp} 730,629,734.78$ & Rp163,668,462.69 & Rp566,961,272.09 & \\
\hline
\end{tabular}

Sumber: Data Olahan Penulis

Tabel 4 Jadwal Pembayaran Sewa Guna Usaha 1 Unit Isuzu Panther LM 2.5 Plus C (SMART)

\begin{tabular}{|c|c|c|c|c|}
\hline Tgl & Angsuran & Bunga & Pokok & Sisa \\
\hline & & & & Rp154,751,798.00 \\
\hline January 05 & Rp2,531,527.67 & Rp967,198.74 & $\mathrm{Rp} 1,564,328.93$ & Rp153,187,469.07 \\
\hline February 05 & Rp2,531,528.67 & Rp957,421.68 & Rp1,574,106.99 & Rp151,613,362.08 \\
\hline March 05 & Rp2,531,529.67 & Rp947,583.51 & Rp1,583,946.15 & Rp150,029,415.93 \\
\hline April 05 & Rp2,531,530.67 & Rp937,683.85 & Rp1,593,846.82 & Rp148,435,569.11 \\
\hline May 05 & Rp2,531,531.67 & Rp927,722.31 & Rp1,603,809.36 & Rp146,831,759.75 \\
\hline June 05 & Rp2,531,532.67 & Rp917,698.50 & Rp1,613,834.17 & Rp145,217,925.58 \\
\hline July 05 & Rp2,531,533.67 & Rp907,612.03 & Rp1,623,921.63 & Rp143,594,003.95 \\
\hline August 05 & Rp2,531,534.67 & Rp897,462.52 & Rp1,634,072.14 & Rp141,959,931.80 \\
\hline September 05 & Rp2,531,535.67 & Rp887,249.57 & Rp1,644,286.09 & Rp140,315,645.71 \\
\hline October 05 & Rp2,531,536.67 & Rp876,972.79 & $\mathrm{Rp} 1,654,563.88$ & Rp138,661,081.83 \\
\hline November 05 & Rp2,531,537.67 & Rp866,631.76 & $\mathrm{Rp} 1,664,905.91$ & Rp136,996,175.92 \\
\hline
\end{tabular}

\begin{tabular}{|c|c|c|c|c|}
\hline December 05 & Rp2,531,538.67 & Rp856,226.10 & Rp1,675,312.57 & Rp135,320,863.35 \\
\hline January 06 & Rp2,531,539.67 & Rp845,755.40 & Rp1,685,784.27 & Rp133,635,079.08 \\
\hline February 06 & $\mathrm{Rp} 2,531,540.67$ & Rp835,219.24 & Rp1,696,321.42 & Rp131,938,757.66 \\
\hline March 06 & Rp2,531,541.67 & Rp824,617.24 & Rp1,706,924.43 & Rp130,231,833.23 \\
\hline April 06 & Rp2,531,542.67 & Rp813,948.96 & Rp1,717,593.71 & Rp128,514,239.52 \\
\hline May 06 & Rp2,531,543.67 & Rp803,214.00 & $\mathrm{Rp} 1,728,329.67$ & Rp126,785,909.85 \\
\hline June 06 & Rp2,531,544.67 & Rp792,411.94 & Rp1,739,132.73 & Rp125,046,777.11 \\
\hline July 06 & Rp2,531,545.67 & Rp781,542.36 & Rp1,750,003.31 & Rp123,296,773.80 \\
\hline August 06 & Rp2,531,546.67 & Rp770,604.84 & Rp1,760,941.83 & Rp121,535,831.97 \\
\hline September 06 & Rp2,531,547.67 & Rp759,598.95 & $\mathrm{Rp} 1,771,948.72$ & Rp119,763,883.25 \\
\hline October 06 & Rp2,531,548.67 & Rp748,524.27 & Rp1,783,024.40 & Rp117,980,858.86 \\
\hline November 06 & Rp2,531,549.67 & Rp737,380.37 & Rp1,794,169.30 & Rp116,186,689.56 \\
\hline December 06 & Rp2,531,550.67 & Rp726,166.81 & Rp1,805,383.86 & Rp114,381,305.70 \\
\hline January 07 & Rp2,531,551.67 & Rp714,883.16 & $\mathrm{Rp} 1,816,668.51$ & Rp112,564,637.19 \\
\hline February 07 & Rp2,531,552.67 & Rp703,528.98 & Rp1,828,023.69 & Rp110,736,613.51 \\
\hline March 07 & Rp2,531,553.67 & Rp692,103.83 & Rp1,839,449.83 & Rp108,897,163.67 \\
\hline April 07 & Rp2,531,554.67 & Rp680,607.27 & Rp1,850,947.39 & Rp107,046,216.28 \\
\hline May 07 & Rp2,531,555.67 & Rp669,038.85 & Rp1,862,516.82 & Rp105,183,699.46 \\
\hline June 07 & Rp2,531,556.67 & Rp657,398.12 & Rp1,874,158.55 & Rp103,309,540.92 \\
\hline July 07 & Rp2,531,557.67 & Rp645,684.63 & Rp1,885,873.04 & Rp101,423,667.88 \\
\hline August 07 & Rp2,531,558.67 & Rp633,897.92 & Rp1,897,660.74 & Rp99,526,007.14 \\
\hline September 07 & Rp2,531,559.67 & Rp622,037.54 & Rp1,909,522.12 & Rp97,616,485.01 \\
\hline October 07 & Rp2,531,560.67 & Rp610,103.03 & Rp1,921,457.64 & Rp95,695,027.38 \\
\hline November 07 & Rp2,531,561.67 & Rp598,093.92 & Rp1,933,467.75 & Rp93,761,559.63 \\
\hline December 07 & Rp2,531,562.67 & Rp586,009.75 & Rp1,945,552.92 & Rp91,816,006.71 \\
\hline January 08 & Rp2,531,563.67 & Rp573,850.04 & Rp1,957,713.63 & Rp89,858,293.08 \\
\hline February 08 & Rp2,531,564.67 & Rp561,614.33 & Rp1,969,950.34 & Rp87,888,342.75 \\
\hline March 08 & Rp2,531,565.67 & Rp549,302.14 & Rp1,982,263.53 & Rp85,906,079.22 \\
\hline April 08 & Rp2,531,566.67 & Rp536,913.00 & Rp1,994,653.67 & Rp83,911,425.55 \\
\hline May 08 & Rp2,531,567.67 & Rp524,446.41 & Rp2,007,121.26 & Rp81,904,304.29 \\
\hline June 08 & Rp2,531,568.67 & Rp511,901.90 & Rp2,019,666.77 & Rp79,884,637.53 \\
\hline July 08 & Rp2,531,569.67 & Rp499,278.98 & Rp2,032,290.68 & Rp77,852,346.84 \\
\hline August 08 & Rp2,531,570.67 & Rp486,577.17 & Rp2,044,993.50 & Rp75,807,353.34 \\
\hline September 08 & Rp2,531,571.67 & Rp473,795.96 & Rp2,057,775.71 & Rp73,749,577.63 \\
\hline October 08 & Rp2,531,572.67 & Rp460,934.86 & Rp2,070,637.81 & Rp71,678,939.83 \\
\hline November 08 & Rp2,531,573.67 & Rp447,993.37 & Rp2,083,580.29 & Rp69,595,359.53 \\
\hline December 08 & Rp2,531,574.67 & Rp434,971.00 & Rp2,096,603.67 & Rp67,498,755.86 \\
\hline \multirow[t]{2}{*}{ January 09} & Rp67,500,000.00 & Rp421,867.22 & Rp67,498,755.86 & Rp0.00 \\
\hline & & & & \\
\hline
\end{tabular}

Sumber: Data Olahan Penulis

\section{Transaksi Sewa Guna Usaha Menurut Peraturan Perpajakan}

Menurut Keputusan Menteri

Keuangan Nomor 1169/KMK.01/1991 tanggal 27 Nopember 1991, kegiatan sewa guna usaha digolongkan sebagai sewa guna usaha dengan hak opsi apabila memenuhi semua kriteria berikut: 


\section{SANG PENCERAH}

Volume 3, Nomor 1, Februari 2017, Hlm. 23-32

Azaluddin: Penerapan Akuntansi Perpajakan Atas ...

1. Jumlah pembayaran sewa guna usaha selama masa sewa guna usaha pertama ditambah dengan nilai sisa barang modal, harus dapat menutup harga perolehan barang modal dan keuntungan lessor.

2. Masa sewa guna usaha ditetapkan sekurang-kurangnya dua tahun untuk barang modal Golongan I, tiga tahun untuk barang modal golongan II dan III dan tujuh tahun untuk golongan bangunan.

3. Perjanjian sewa guna usaha memuat ketentuan mengenai opsi bagi lessee.

Transaksi Sewa Guna usaha yang terjadi pada PT.IGLAS (Persero) atas pembelian 3 unit Toyota Kijang LGX dan 1 unit Isuzu Panther apabila penulis uji dengan tiga kriteria tersebut akan menghasilkan kesimpulan sebagai berikut:

1. Tiga unit Toyota Kijang LGX

Kriteria 1:

Jumlah pembayaran sewa guna usaha

selama 4 tahun : Rp10.701.284,55 x 48

bulan $\quad=$ Rp. 513.661.658,00

Nilai hak opsi $=$ Rp216.000.000,00

Jumlah $\quad=$ Rp. 730.629.734,00

Harga Perolehan barang modal + keuntungan (bunga) : Rp566.961.272,00 + Rp163.668.462,00 = Rp730.629.734,00

Karena jumlah angsuran selama masa sewa guna usaha ditambah nilai sisa dapat menutupi harga perolehan barang modal + bunga lessor, maka kriteria 1 sebagai transaksi capital lease terpenuhi.

Kriteria 2:

Berdasarkan Keputusan Menteri Keuangan No.82/KMK.04/1995 tanggal 7 Februari 1995 tentang penggolongan aktiva berwujud untuk keperluan penyusutan, bahwa kendaraan Toyota Kijang tersebut digolongkan sebagai barang modal golongan II.

Masa sewa guna usaha menurut perjanjian adalah 48 bulan (4 tahun), maka kriteria 2 sebagai transaksi capital lease terpenuhi.

\section{Kriteria 3:}

Menurut perjanjian sewa guna usaha, lessee memiliki hak opsi untuk membeli aktiva sewa guna usaha pada akhir masa sewa guna usaha, maka kriteria 3 sebagai transaksi capital lease terpenuhi.

Kesimpulan Akhir dengan terpenuhinya semua kriteria yang dipersyaratkan oleh ketentuan perpajakan yang berlaku, maka transaksi sewa guna usaha atas 3 unit Toyota Kijang LGX dapat dikategorikan sebagai transaksi capital lease.

2. Satu unit Isuzu Panther LM 2.5 Plus C (SMART) Manual

Kriteria 1 :

Jumlah pembayaran sewa guna usaha selama 4 tahun : Rp2.531.574,7 x 48 bulan

$$
=\text { Rp121.514.456,00 }
$$

Nilai hak opsi $=$ Rp67.500.000,00

Jumlah $\quad=$ Rp189.435.079,00

Harga Perolehan barang modal + keuntungan (bunga) : Rp154.751.798,00 + Rp34.683.281,00 = Rp189.435.079,00

Karena jumlah angsuran selama masa sewa guna usaha ditambah nilai sisa dapat menutupi harga perolehan barang modal + bunga lessor, maka kriteria 1 sebagai transaksi capital lease terpenuhi.

Kriteria 2:

Berdasarkan Keputusan Menteri Keuangan No.82/KMK.04/1995 tanggal 7 Februari 1995 tentang penggolongan aktiva berwujud untuk keperluan penyusutan, bahwa kendaraan Isuzu Panther tersebut digolongkan sebagai barang modal golongan II. Masa sewa guna usaha menurut perjanjian adalah 48 bulan (4 tahun), maka kriteria 2 sebagai transaksi capital lease terpenuhi. 


\section{SANG PENCERAH}

Volume 3, Nomor 1, Februari 2017, Hlm. 23-32

Azaluddin: Penerapan Akuntansi Perpajakan Atas ...

\section{Kriteria 3:}

Menurut perjanjian sewa guna usaha, lessee memiliki hak opsi untuk membeli aktiva sewa guna usaha pada akhir masa sewa guna usaha, maka kriteria 3 sebagai transaksi capital lease terpenuhi.

Kesimpulan Akhir dengan terpenuhinya semua kriteria yang dipersyaratkan oleh ketentuan perpajakan yang berlaku, maka transaksi sewa guna usaha untuk kendaraan Isuzu Panther LM 2.5 Plus C (SMART) Manual dapat dikategorikan sebagai transaksi capital lease.

\section{Perlakuan Akuntansi Pajak Terhadap Transaksi Sewa Guna Usaha Sesuai dengan Ketentuan Peraturan Perpajakan yang Berlaku}

Peraturan perpajakan yang terkait dengan transaksi sewa guna usaha yaitu :

1. Keputusan Menteri Keuangan No.1169/KMK.01/1991 tanggal 27 Nopember 1991 tentang kegiatan sewa guna usaha (leasing).

2. Surat Edaran Dirjen Pajak No. SE29/PJ.42/1992 tanggal 19 Desember 1991 tentang perlakuan Pajak Penghasilan terhadap kegiatan sewa guna usaha (leasing).

Perlakuan Akuntansi Pajak terhadap transaksi sewa guna usaha pada PT.IGLAS (Persero) atas pembelian 3 unit Toyota Kijang LGX dan 1 unit Isuzu Panther LM 2.5 Plus C (SMART) sesuai dengan peraturanperaturan perpajakan tersebut adalah sebagai berikut:

a. Berdasarkan kriteria yang telah diuji di atas, sesuai dengan Keputusan Menteri Keuangan No.1169/KMK.01/1991 tanggal 27 Nopember 1991, maka transaksi sewa guna usaha yang terjadi pada PT.IGLAS (Persero) tersebut dapat dikategorikan sebagai transaksi sewa guna usaha dengan hak opsi (capital lease).

b. Atas transaksi sewa guna usaha dengan hak opsi tersebut, PT IGLAS dikenakan Pajak Pertambahan Nilai sebesar:
1. Tiga unit Toyota Kijang LGX Rp566.961.272,00 x 10\%= Rp56.696.127,00

2. Satu unit Isuzu Panther LM 2.5 Plus C (SMART) Manual Rp154.751.798,00 x $10 \%=$ Rp15.475.179,00

Namun berdasarkan UndangUndang nomor 18 tahun 2000 tentang Pajak Pertambahan Nilai dan Pajak Penjualan atas Barang Mewah, PPN Masukan atas semua transaksi tersebut tidak dapat dikreditkan.

c. PT IGLAS tidak boleh melakukan penyusutan atas kendaraan tersebut selama masa sewa guna usaha. Penyusutan baru boleh dilakukan setelah PT IGLAS menggunakan hak opsinya untuk membeli kendaraan tersebut.

d. Pembayaran sewa guna usaha yang dibayar atau terutang oleh PT IGLAS merupakan biaya yang dapat dikurangkan dari penghasilan bruto, rinciannya adalah sebagai berikut :

1. Tahun Pajak 2002

Tiga unit Toyota Kijang LGX =

Rp128.415.414,00

2. Tahun Pajak 2003

Tiga unit Toyota Kijang LGX =

Rp128.415.414,00

3. Tahun Pajak 2004

Tiga unit Toyota Kijang LGX =

Rp128.415.414,00

4. Tahun Pajak 2005

Tiga unit Toyota Kijang LGX =

Rp128.415.414,00

Satu unit Isuzu Panther =

Rp30.378.896,00

5. Tahun Pajak 2006

Satu unit Isuzu Panther =

Rp30.378.896,00

6. Tahun Pajak 2007

Satu unit Isuzu Panther=

Rp30.378.896,00

7. Tahun Pajak 2008

Satu unit Isuzu Panther =

Rp30.378.896,00 


\section{SANG PENCERAH}

Volume 3, Nomor 1, Februari 2017, Hlm. 23-32

Azaluddin: Penerapan Akuntansi Perpajakan Atas ...

e. PT IGLAS tidak berkewajiban memotong Pajak Penghasilan pasal 23 atas transaksi sewa guna usaha tersebut.

Berdasarkan data-data transaksi sewa guna usaha di atas, maka dapat disusun ayat jurnalnya sebagai berikut :

Tabel 5 Tiga unit Toyota Kijang LGX

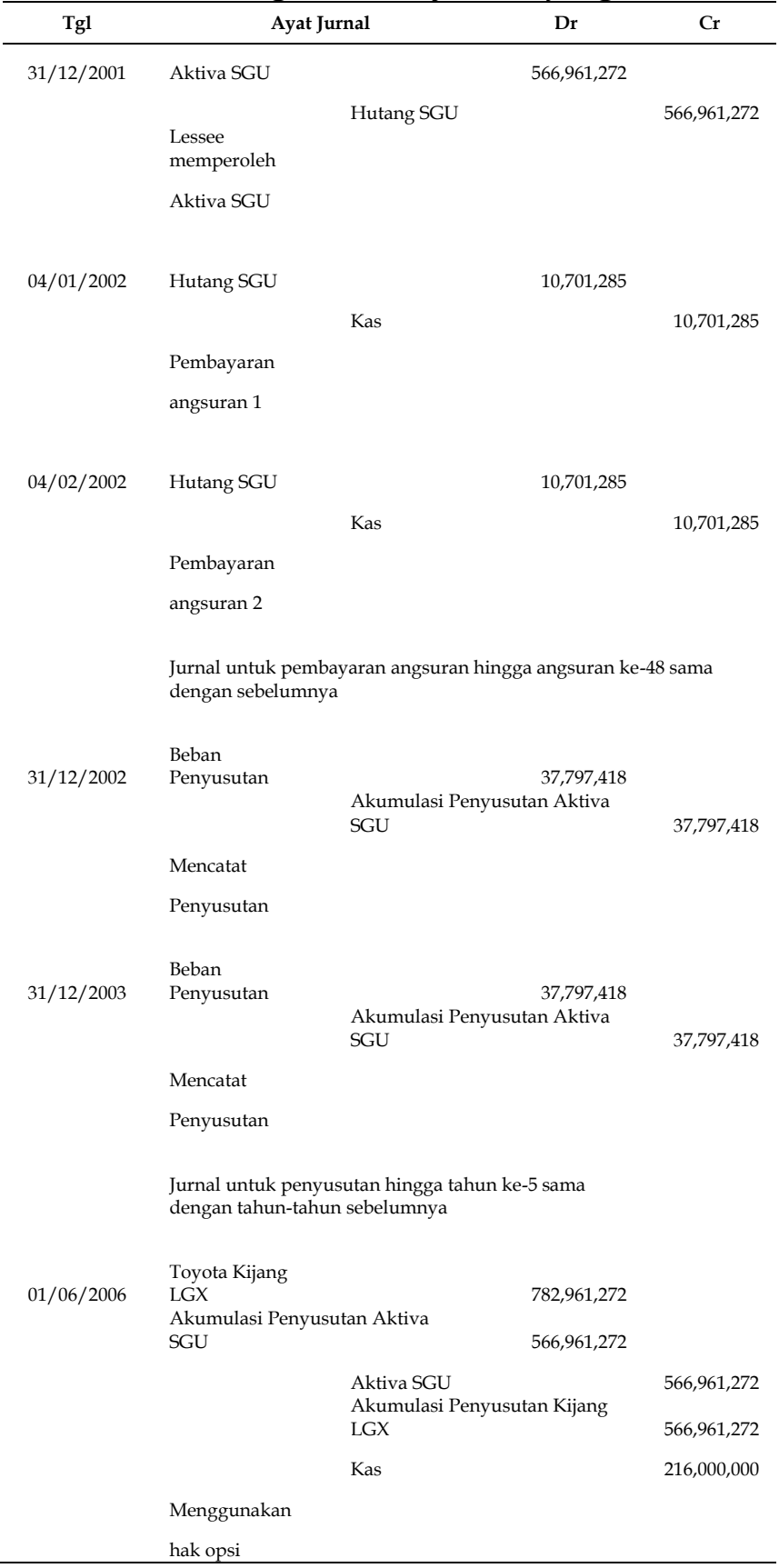

Tabel 6 Satu Unit Isuzu Panther LM 2.5 Plus C (SMART) Manual

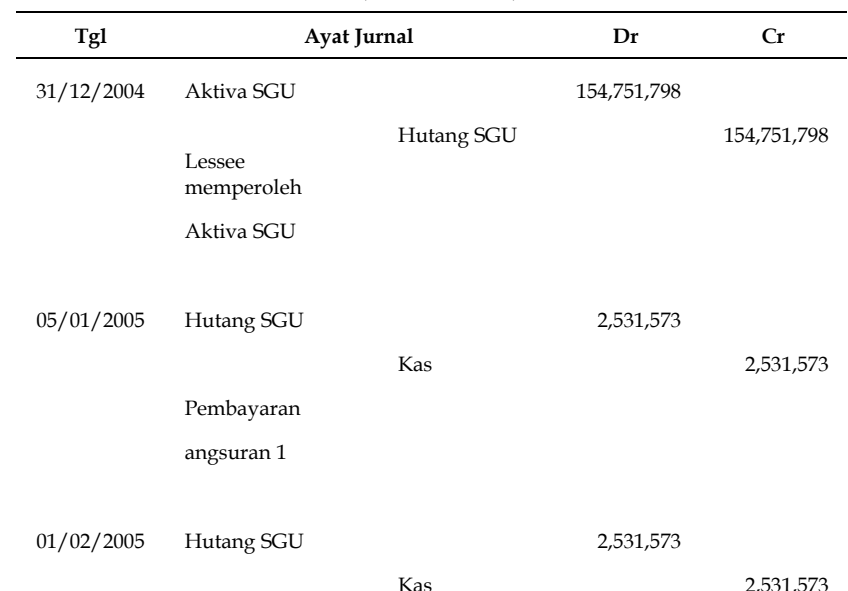

Pembayaran

angsuran 2

Jurnal untuk pembayaran angsuran hingga angsuran ke-48 sama dengan sebelumnya

\begin{tabular}{|c|c|c|c|c|}
\hline \multirow[t]{3}{*}{$31 / 12 / 2005$} & Beban Penyusutan & $\begin{array}{l}\text { Akumulasi } \\
\text { Penyusutan } \\
\text { Aktiva SGU }\end{array}$ & $51,583,932$ & $51,583,932$ \\
\hline & Mencatat & & & \\
\hline & Penyusutan & & & \\
\hline \multirow[t]{7}{*}{$31 / 12 / 2006$} & Beban Penyusutan & & $51,583,932$ & \\
\hline & & \multicolumn{3}{|l|}{$\begin{array}{l}\text { Akumulasi } \\
\text { Penyusutan }\end{array}$} \\
\hline & & \multicolumn{2}{|l|}{ Aktiva SGU } & $51,583,932$ \\
\hline & Mencatat & & & \\
\hline & Penyusutan & & & \\
\hline & \multicolumn{4}{|c|}{$\begin{array}{l}\text { Jurnal untuk penyusutan hingga tahun ke- } 5 \text { sama } \\
\text { dengan tahun-tahun sebelumnya }\end{array}$} \\
\hline & Isuzu Panther LM & & & \\
\hline \multirow[t]{7}{*}{$10 / 01 / 2009$} & 2.5 & & $222,251,798$ & \\
\hline & Akumulasi Penyusu & n Aktiva SGU & $154,751,798$ & \\
\hline & & \multicolumn{2}{|c|}{$\begin{array}{l}\text { Aktiva SGU } \\
\text { Akumulasi Penyusutan Isuzu }\end{array}$} & $154,751,798$ \\
\hline & & \multicolumn{2}{|c|}{ Panther } & $154,751,798$ \\
\hline & & \multicolumn{2}{|l|}{ Kas } & $67,500,000$ \\
\hline & Menggunakan & & & \\
\hline & hak opsi & & & \\
\hline
\end{tabular}

\section{Simpulan}

Simpulan penelitian ini adalah (1) Perlakuan Akuntansi Sewa Guna Usaha atas kendaraan dinas selama tahun 2000-2004 di PT IGLAS hanya dari sisi akuntansi komersial saja, dari sisi fiskal belum 


\section{SANG PENCERAH}

Volume 3, Nomor 1, Februari 2017, Hlm. 23-32

Azaluddin: Penerapan Akuntansi Perpajakan Atas ...

diterapkan, padahal terdapat perbedaanperbedaan perlakuan diantara keduanya. Misalkan masalah penyusutan, prinsip akuntansi komersial mengakui adanya penyusutan atas aktiva sewa guna usaha selama masa sewa guna usaha, sedangkan ketentuan fiskal tidak, ketentuan fiskal memperkenankan pengakuan penyusutan setelah lessee menggunakan hak opsinya untuk membeli aktiva tersebut; (2) Pembayaran angsuran sewa guna usaha yang dibayar setiap bulannya kepada lessor dicatat sebagai beban sewa oleh lessee dan menurut ketentuan perpajakan merupakan biaya yang deductable, yaitu dapat diakui sebagai biaya yang mengurangi Penghasilan bruto; dan (3) PPn Masukan atas pembelian aktiva kendaraan yang dilakukan oleh PT IGLAS, menurut ketentuan UU No. 18 tahun 2000 tentang Pajak Pertambahan Nilai, tidak dapat dikreditkan, sehingga pencatatannya dikapitalisaskan ke harga perolehan.

\section{Daftar Pustaka}

Arikunto, Suharsimi 2005. Prosedur Penelitian Suatu Pendekatan Praktik, Jakarta: PT. Rineka Cipta.

Budiono, 1989. Ekonomi Moneter, Yogyakrta: BPFE.

Firdaus, Muhammad, dkk, 2005. Fatwa-Fatwa Ekonomi Syariah Kontemporer, Jakarta: Renaisan.

Fauzi, Muchamad, 2011. Metode penelitian Kuantitatif, Semarang: Walisongo Press.

Ghozali, Imam, 2006. Apilkasi Analisis Multivariate dengan Program SPSS, Semarang: Undip.
Marshall, Robert dan Miranda, Kamus Populer Uang dan Bank, Jakarta: Ladang Pustaka dan Intimedia.

Puspopranoto, Salwodjo, 2004. Keuangan Pebankan dan Pasar Keuangan, Jakarta: LP3ES,

Sarwoko, 2005. Dasar-Dasar Ekonometrika, Yogyakarta: Andi.

Sugiyono. 2013. Statiska untuk Penelitian, Bandung: Alfabeta.

Sumiyanto, Ahmad, 2005. Problem dan Solusi Transaksi Mudharabah, Yogyakarta: Magistra Insania Press.

Suprayitno, Eko, 2005. Ekonomi Islam, Yogyakarat: Graha Ilmu.

Teguh, Muhammad, 2005. Metodologi Penelitian Ekonomi, Jakarta: Raja Grafindo Persada.

Winarno, Sigit dan Sujana Ismaya, 2007. Kamus Besar Ekonomi, Bandung: Pustaka Grafika. 